\title{
How do emotional intelligence and behavioral biases of investors determine their investment decisions?
}

\author{
Saloni Raheja \\ Department of Commerce and Business Management, DAV University, \\ Jalandhar, India, and \\ Babli Dhiman \\ Mittal School of Business, Lovely Professional University, Phagwara, India
}

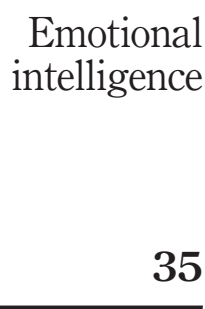

Received 23 December 2019 Revised 21 February 2020 Accepted 10 March 2020

\begin{abstract}
Purpose - In earlier studies, research has shown that EI is the only element, which influences the ways in which people develop in their lives, jobs and social skills control their emotions and get along with other people. It is EI that dictates the way people deal with one another and understand emotions. The research gap is to explore the impact of behavioral factors and investors psychology on their investment decision-making.

Design/methodology/approach - The information was gathered from 500 financial specialists. The region of research was the financial specialists who contribute through LSC Securities Ltd. in Punjab State. The purposive testing system was used in this examination.

Findings - The investigation found that the positive connection between the conduct predispositions of the financial specialists and venture choices of the speculators and positive connection between enthusiastic insight of the financial specialists and their venture choices. Yet, the authors found that the enthusiastic insight better foresees the venture choices of the financial specialists than the conduct predispositions of the speculators. Among the different elements of conduct inclinations of the speculator's lament and carelessness are identified with the financial specialist's venture choices. Among the various estimations of eager understanding - care, dealing with emotions, motivation, empathy and social aptitudes are related to the hypothesis decisions of the monetary pros.

Research limitations/implications - The sample selection was based on purposive sampling, rather than a random probability sample. The sample was area specific, restricted only to Ludhiana Stock Exchange in Punjab state. Therefore, the results of the study cannot be generalized with certainty to all the investors investing through other exchanges in other states. The inferences are based on the assumption that the data provided by the investors are true and correct. The findings may be relevant for other stock exchanges as that of the Ludhiana Stock Exchange. However, the authors do not claim the generalization of the results.

Practical implications - This study also helps to understand the relationship between investment decision-making and risk tolerance of investors. It will helpful for the financial advisors to know the behavioral biases of investors while making an investment decision, and therefore, they can advise investors properly to mitigate such biases. It may help the investors in understanding the subjective part of their behavior and control their emotions while taking decisions for their investment in stock market options.
\end{abstract}

(C) Saloni Raheja and Babli Dhiman. Published in Rajagiri Management Journal. Published by Emerald Publishing Limited. This article is published under the Creative Commons Attribution (CC BY 4.0) license. Anyone may reproduce, distribute, translate and create derivative works of this article (for both commercial and non-commercial purposes), subject to full attribution to the original publication and authors. The full terms of this license may be seen at http://creativecommons.org/ licences/by/4.0/legalcode

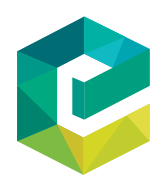

Rajagiri Management Journal Vol. 14 No. 1,2020

pp. 35-47 p-ISSN 0972-9968 p-ISSN 0972-9968 DOI 10.1108/RAMJ-12-2019-0027 
RAMJ

14,1

Social implications - This research will help investment advisors and finance professionals to judge investors' attitudes toward risk in a better way, which leads to better investment decisions.

Originality/value - This study is my own study and it is original and has not been published anywhere.

Keywords Behavioral biases, Emotional intelligence, Investment decisions, Multiple regression, Relationship

Paper type Research paper

\section{Introduction}

In the present situation, money has a significant influence on everybody's life. So as to maintain a strategic distance from various kinds of issues throughout everyday life, the individual ought to put the cash in various sorts of roads. The Indian budgetary framework supports the reserve funds among the financial specialists and channels them to their ideal and powerful use. In the present aggressive time, the different speculation roads are accessible to the speculators. Financial specialists when all is said in done have the energy to put resources into those specific roads, which will deliver the most extreme comes back with the least dangers. The speculators settle on the venture choices based on the various variables. The venture choices remember for different speculation procedures, recurrence of the venture, timeframe, targets of speculation, factors influencing speculation choices and some more. The conduct predispositions are the most significant factor while settling on venture choices (Camerer, 1997; Bailey, 2012; Breuer et al., 2014). This segment manages the presentation of the components of the passionate insight and the elements of the conduct predispositions of the financial specialists.

\subsection{Emotional intelligence}

As per Goleman (2006), enthusiastic insight is what helps the financial specialists to settle on the choices in a superior manner. Enthusiastic intelligence is: "the limit with respect to perceiving our own sentiments and those in others, for inspiring ourselves, for overseeing feelings well in ourselves and in our connections." The passionate knowledge includes:

- Self-mindfulness: self-comprehension and capacity to comprehend the feelings.

- Handling feelings: know how to quiet yourself.

- Motivation: ready to set your own specific goals and work to achieve those destinations, able to set little walks to achieve immense targets.

- Empathy: know how to comprehend the sentiments of others.

- Social aptitudes: ready to coincide with others, ready to work excellently in parties and social occasions.

\subsection{Behavioral biases}

The investigation of social fund centers on how people make and deal with their monetary resources. Conduct account infers the mental and sociological components, which influence the choices of the financial specialists whether an individual, gathering and others.

Conservatism: it suggests that the individuals are not prepared to acknowledge the progressions and they will set aside more effort to control the changes.

Overconfidence: the financial specialists become presumptuous while foreseeing the future that they can conjecture the future better. 
Herding: herding is a circumstance when the individual cannot take their very own choices and they do what most of the individuals do.

Regret: a lament hypothesis says that individuals anticipate lament in the event that they settle on an off-base decision and think about this forecast while taking choices in the future.

\section{Review of literature}

Kunnanatt (2004) discussed the emotional intelligence. He observed that people with high emotional intelligence would produce a win-win relationship and people with low emotional intelligence would produce a win-lose relationship. The emotional intelligence training programs would change both the inside and outside relationships of participants and better attitudes, clearer perceptions and productive affiliations in life. Avsec et al. (2009) analyzed the connection between the emotional intelligence of Croatian and Slovenian college understudies and their identity attributes. The information was gathered from 257 college understudies and 171 college understudies. The information was dissected by regression, relationship and two way ANOVA. They reasoned that extraversion trait and conscientiousness trait were vital indicators and the neuroticism trait was the most grounded indicator.

Inaishi et al. (2010) considered the arrogant budgetary expert lead in the protection trade by entertainment. They contemplated that when there was a climb in design then the money related experts got thoughtless. Landa et al. (2010) got some information about the relationship among energized information, character properties and mental tendencies in understudies. They inspected that there was a sure connection between lively thought and neuroticism and there was a negative relationship of empowered ideas with responsiveness and opportunity. The invigorated clearness was adversely related to neuroticism and was related to extraversion. Ezadinea et al. (2011) researched the impact of EI and its measurements on portfolio execution. The information was gathered from 122 Iranian shareholders. The information was broke down with the assistance of regression. They had also used $t$-tests for analysis. They inferred that there was a beneficial outcome EI on portfolio execution. They found that portfolio execution and return was influenced by the experience of the speculators. Masomi and Ghayekhloo (2011) isolated the impact of the social factors on the wander decisions of the budgetary supervisors. They found that regret was one of the standard variables, which impact the speculation decisions of the examiners. Garkaz and Mehrvarzi (2012) isolated the connection between eager learning and execution of business firms in the Tehran Stock Exchange. There was a connection between selfaffiliation and execution, yet, there was no connection between social consideration and execution. Nawi et al. (2012) picked the connection between fiery information and character trait among school pioneers in high performance schools in Malaysia. They found that legitimacy, responsiveness to comprehension, extraversion and fittingness were emphatically related to energetic learning of the school's teacher pioneers. The extraordinary certainty had more grounded association with vivacious learning than the

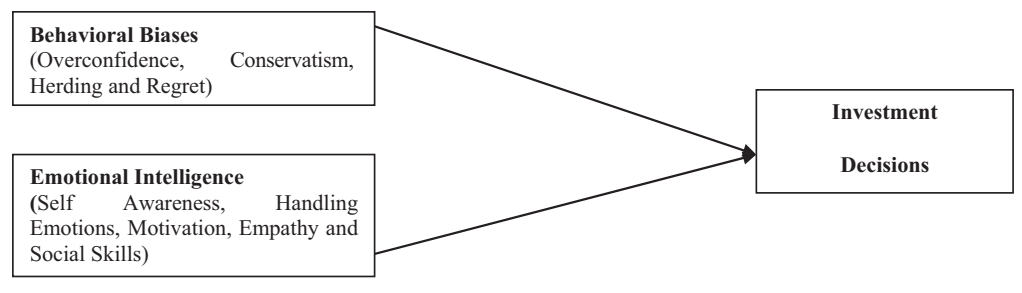

Figure 1.

Theoretical framework of the study 
RAMJ

14,1

other character characteristics. Ramanujam and Ramkumar (2012) determined the attitude toward risk and personality traits of women in the stock market. The collection of data was done from 360 investors. The $t$-test, factor analysis and percentages were used in the study. Zaidi and Tauni (2012) perceived the association between personality traits, demographics and overconfidence bias of monetary experts in the Lahore Stock Exchange. The data was accumulated from 170 respondents and was destitute somewhere around chi-square $\left(\chi^{2}\right)$ and relationship. They gathered that there was a certain association between pomposity inclination and extroversion and an indirect association between overconfidence tendency and neuroticism. Bashir et al. (2013) investigated the effect of economics components and character qualities on the direct tendencies and danger taking behavior in Pakistan. The data was accumulated from 225 lenders and cash understudies. The data was dismembered by SEM. They assumed that character characteristics had basic association beside mien sway with pretentiousness, gathering behavior and risk taking. The measurement factors had no association with direct tendencies. Sami and Rizvi (2013) found that lively learning was exceptionally related to life satisfaction and character attributes had an inverse association with life satisfaction. They furthermore watched that the markers of life satisfaction intra-specific thought and neuroticism were in the made individuals. Pervez (2014) found that the lively understanding attributes of the cash related specialists are related to experience choices of the scholars. Pirayesh (2014) assessed the effect of stimulating information on theoretical frameworks of retail money related specialists in the Tehran Stock Exchange. He construed that there was a positive connection between stimulated learning and hypothesis decisions. He found that there was certain and connection between chance hesitant and estimations of stimulating information. Rzeszutek et al. (2015) they found that not simply that unremitting retail researchers were unprotected against various lead slants while picking decisions yet also that the level of lack of protection was more grounded in this get-together than among the people who were basically delicately connected with contributing. Alquraan et al. (2016) analyzed the association between the hypothesis decisions and the lead factors. They found that the egotism had a basic association with the hypothesis decisions of the monetary experts and there was no association between the swarming conduct and the endeavor decisions of the examiners. Chavali and Mohanraj (2016) inspected the association between danger obstruction and theory decisions and found that the examiners lean toward sure increment instead of an uncertain future. Tanvir et al. (2016) contemplated the connection between vivacious appreciation and theory decisions. They found that there was an extraordinary effect of care, self affiliation, sympathy yet low obsession with relationship affiliation. Sashikala and Chitramani (2017) focused on identifying the constructs necessary to identify the EI of investors through an extensive review stating the role that emotional intelligence plays in the investment behavior of the investor. Muttath and Menachery (2018) analyzed the similarities or differences among high and low emotional intelligence and investment decisions. Zahera and Bansal (2018) studied the behavioral patterns of individual investors, institutional investors and financial advisors. Choudhary and Subramanian (2019) found that risk tolerance had a strong resemblance to the investment decision. Raheja and Dhiman (2019) focused on the relationship between the behavioral biases and risk tolerance of the investors and the relationship between the behavioral biases and the investment decisions of the investors.

From the above discussion, we endeavor to comprehend the relation between investment decisions and the emotional intelligence of the investors. We can say that people take different investment decisions depending on their emotional intelligence and their behavioral biases. Some emotional intelligence dimensions have direct relation and some 
have an indirect relation with the investment decisions. There is a relation between behavioral biases and investment decisions of investors also. Some dimensions of behavioral biases have direct relation and some have an indirect relation with the investment decisions of the investors.

\section{Objectives of the study}

- To study the relation between the dimensions of emotional intelligence and investment decisions; and

- To study the relation between the dimensions of behavioral biases and investment decisions.

On the basis of the above objectives, the following hypotheses have been framed and are tested:

HO. There is no relation between emotional intelligence and investment decisions of investors.

H1. There is relation between emotional intelligence and investment decisions of investors.

HO. There is no relation between behavioral biases and investment decisions of investors.

H2. There is relation between behavioral biases and investment decisions of investors.

In this study, the behavioral biases and emotional intelligence are the independent variables and the investment decisions of the investors are the dependent variable. The dimensions of behavioral biases are coded as overconfidence $\mathrm{X}_{11}$, conservatism $\mathrm{X}_{12}$, herding $\mathrm{X}_{13}$ and regret $\mathrm{X}_{14}$ and the dimensions of emotional intelligence are coded as self awareness $\mathrm{X}_{21}$, handling emotions $\mathrm{X}_{22}$, motivation $\mathrm{X}_{23}$, empathy $\mathrm{X}_{24}$ and social skills $\mathrm{X}_{25}$.

\section{Research methodology}

Test size: the information was gathered from 500 financial specialists.

Inspecting area: the region of research was the financial specialists who contribute through LSC Securities Ltd. in Punjab State.

Inspecting technique: the purposive testing system was used in this examination. It is a non-likelihood testing system, which depends on the highlights of a populace and the target of the examination. The purposive testing strategy is otherwise called critical examining or particular inspecting or abstract inspecting. It is additionally founded on the assessment of the master.

Poll: the institutionalized survey has been used to gather information from financial specialists. The enthusiastic insight scale, conduct predispositions scale and the venture choices scale have been used in the investigation.

The standardized scale for emotional intelligence (Goleman, 2001), which is a reliable and validated 50-item, five-point Likert scale that measures the components of emotional intelligence, empathy, self-awareness, motivation, managing emotions and social skills.

The standardized scale for behavioral biases scale was taken from Chin (2012), which is a reliable and validated 24 -item, five-point Likert scale that measures the behavioral aspects of the individuals i.e. overconfidence, regret, herding behavior and conservatism. 
RAMJ

14,1

The standardized scale for investment decisions were also taken from which is a reliable and validated 35-item, five-point Likert scale (Hameed, 2012).

Wellsprings of information: for this examination, the essential information was gathered from financial specialists with the assistance of institutionalized surveys from the speculators of securities exchange and optional information was gathered from diaries, books and sites and from the audit of writing.

Pilot study: a pilot study had been done on 50 investors to test the reliability and the Cronbach's alpha $(\alpha)$ was 0.857 , which is more than 0.6 . It shows that the data was reliable.

\section{Analysis}

This section represents the relationship among the investors' emotional intelligence, behavioral biases and investment decisions. This section is divided into three parts - first part describes the relation between the dimensions of the behavioral biases and the investment decisions of the investors; the second part describes the relation between the dimensions of the emotional intelligence and the investment decisions of the investors; and third part describes the overall relation among the behavioral biases, emotional intelligence and the investment decisions of the investors. Multiple regression techniques were applied to test the relationship between these variables.

\subsection{Relation between behavioral biases and investment decisions of investors}

This section deals with the relation between the dimensions of the behavioral biases and the investment decisions of the investors. On the basis of this, the following hypotheses are framed:

HO. There is no relation between overconfidence and investment decisions of investors.

H1a. There is relation between overconfidence and investment decisions of investors.

HO. There is no relation between conservatism and investment decisions of investors.

H1b. There is relation between conservatism and investment decisions of investors.

HO. There is no relation between herding and investment decisions of investors.

H1c. There is relation between herding and investment decisions of investors.

HO. There is no relation between regret and investment decisions of investors.

H1d. There is relation between regret and investment decisions of investors.

Table 1 shows that the fitted model is quantifiably vital at $p<0.05$. The model decides an estimated level at 0.615 or $61.5 \%$. It shows that there is a connection between the conduct inclinations and the venture choices of the financial specialists. It shows that how precisely a

Table 1.

Coefficients from multiple regression model

Intercept $=1.004, \mathrm{R}=0.615, \mathrm{R}^{2}=0.379$ and $\mathrm{F}=74.571$

Independent variable

Dependent variable (investment decisions)

(behavioral biases)

Overconfidence $\mathrm{X}_{11}$

Conservatism $\mathrm{X}_{12}$

Herding $\mathrm{X}_{13}$

Regret $\mathrm{X}_{14}$

$\beta$

0.385

0.024

0.001

0.218

$t$

11.578

1.202

0.068

8.466

Sig. 
model of relapse will anticipate the future results. The $R^{2}$ chooses 0.379 or $37.9 \%$ explains the variability of the speculation choices. The assessment used ANOVA to become familiar with the significance of the model in Table 1 . The table shows that the factors are critical at $F(5,494)=75.471, p<0.05$, which shows that the model is a solid match for the information. In this manner, it shows that for the $t$-test the factors X11 and X14 at 0.05 level are critical. As the sig esteem for arrogance predisposition and lament inclination is under 0.05 .

In this manner, the theories $H 1 b$ and $H 1 c$ are not acknowledged and $H 1 a$ and $H 1 d$ are acknowledged. It implies that there is a connection between arrogance predisposition and investment choices of financial specialists. There is a connection between the lament predisposition and the speculation choices of the speculators. There is no connection between conservatism inclination and investment choices of financial specialists. There is no connection between the crowding predisposition and the speculation choices of the financial specialists.

The intercept of the relapse condition is 1.428 . The beta $(\beta)$ coefficients of the factors, which are huge $-0.385(\mathrm{X} 11)$ and 0.218 (X14).

Among every one of the components of conduct predispositions, the most elevated estimation of coefficients is for variable X11 (overconfidence), which shows that pomposity is the most significant indicator of investment choices. There is a connection between the pomposity inclination and investment choices of the financial specialists. When there is a one-point increment in carelessness inclination it will prompt positive difference in 0.385 focuses on investment choices of financial specialists. The financial specialists at some point may become careless about their very own speculation choices. They believe that they can anticipate the future superior to the others, they become careless about their choices. They believe that they can take their speculation choices and it will consistently be correct. The outcomes are connected with the past writing of Norsinger (2002).

There is a critical connection between lament inclination and speculation choices of financial specialists. When there is a one-point increment in lament inclination there will be a positive difference in 0.218 focuses on venture choices of financial specialists. The financial specialists who consider their past experience put more and put safely in securities exchange and go out on a limb. Everybody will have the experience of feeling mourn for the span of the standard day by day presence and it is common. The cash related experts feel regret when they purchase at a significant expense and offer easily. They will in general hold the stocks excessively long until the point that the minute that the expense achieves lower than the getting cost. This is reliable with the discoveries of Shefrin (2009). There is no noteworthy connection between conservatism and speculation choices. There is no noteworthy connection between crowding and venture choices. The outcomes additionally gain support from the earlier discoveries Chin (2012). It shows that a few financial specialists do not pursue the activities of the others so as to put resources into securities exchange. They take their very own choices while putting resources into securities exchange. It shows that a few people do not avoid changes when they put resources into securities exchange. They change their choices as indicated by the new data and new innovation emerges. They do not adhere to the old ones.

\subsection{Relation between emotional intelligence and investment decisions of investors}

This section deals with the relation between the dimensions of emotional intelligence and the investment decisions of the investors. On the basis of this, the following hypotheses are framed:

HO. There is no relation between self awareness and investment decisions of investors. 
RAMJ

14,1

H2a. There is relation between self awareness and investment decisions of investors.

HO. There is no relation between handling emotions and investment decisions of investors.

$H 2 b$. There is relation between handling emotions and investment decisions of investors.

HO. There is no relation between motivation and investment decisions of investors.

$H 2 c$. There is relation between motivation and investment decisions of investors.

HO. There is no relation between empathy and investment decisions of investors.

H2d. There is relation between empathy and investment decisions of investors.

HO. There is no relation between social skills and investment decisions of investors.

H2e. There is relation between social skills and investment decisions of investors.

Table 2 demonstrates that the model is fit and is factually critical at $p<0.05$. The model infers an expectation level at 0.664 or $66.4 \%$ for each penny. It demonstrates that there is a connection between the passionate knowledge and the venture choices of the financial specialists. The $R^{2}$ esteem decides 0.441 or $44.1 \%$ for every penny clarifies the changeability of the investment decisions.

The ANOVA decides the hugeness of the relapse demonstrates in Table 2. The table uncovers that the factors are critical at $F(5,494)=77.959, p<0.05$, which demonstrates that the model is fit for the information.

It shows in Table 2 that the $t$-test is significant for all the variables $\mathrm{X}_{21}, \mathrm{X}_{22}, \mathrm{X}_{23}, \mathrm{X}_{24}$ and $\mathrm{X}_{25}$ at 0.05 level. Thus, the hypotheses $\mathrm{H2a}, \mathrm{H} 2 \mathrm{~b}, \mathrm{H} 2 \mathrm{c}, \mathrm{H} 2 \mathrm{~d}$ and $\mathrm{H} 2 \mathrm{e}$ are accepted. It means that there is a relation between all the dimensions of emotional intelligence that is self awareness, handling emotions, motivation, empathy, social skills and investment decisions of the investors. The intercept of the regression equation is 0.843 . The $\beta$ coefficients of the variables, which are significant are $0.228\left(\mathrm{X}_{21}\right), 0.077\left(\mathrm{X}_{22}\right), 0.285\left(\mathrm{X}_{23}\right),-0.088\left(\mathrm{X}_{24}\right)$ and 0.165 $\left(\mathrm{X}_{25}\right)$.

In this manner from the table, we discovered that among every one of the elements of the enthusiastic insight, the most noteworthy estimation of the coefficient is for motivation, which shows that inspiration is the most significant indicator of investment choices of the speculators. There is a noteworthy connection between mindfulness and investment choices of the financial specialists. When there is one point increment in mindfulness there will be a positive difference in 0.228 focuses on investment choices of speculators. It shows that when

Table 2.

Coefficients from multiple regression model
Intercept $=0.843, \mathrm{R}=0.664, \mathrm{R}^{2}=0.441$ and $\mathrm{F}=77.959$

Independent variable

(emotional intelligence)

Self awareness $\left(\mathrm{X}_{21}\right)$

Handling emotions $\left(\mathrm{X}_{22}\right)$

Motivation $\left(\mathrm{X}_{23}\right)$

Empathy $\left(\mathrm{X}_{24}\right)$

Social skills $\left(\mathrm{X}_{25}\right)$
Dependent variable (investment decisions)

\begin{tabular}{rrc}
\multicolumn{1}{c}{$\beta$} & \multicolumn{1}{c}{$t$} & Sig. \\
0.228 & 6.180 & 0.000 \\
0.077 & 2.584 & 0.010 \\
0.285 & 6.110 & 0.000 \\
-0.088 & -2.301 & 0.022 \\
0.165 & 4.343 & 0.000
\end{tabular}


the financial specialists know their own feelings and their impact of feelings on the venture choices then he will contribute appropriately. There is a huge connection between taking care of feelings and investment choices of financial specialists. When there is a one-point increment in dealing with feelings it will bring a positive difference in 0.077 focuses on investment choices of financial specialists. At the point when the financial specialists know how to remain positive under tension put more in securities exchange. When there is one point increment in the inspiration it will get a positive difference in 0.285 focuses on investment choices of speculators. There is a connection between inspiration and investment choices. The examiners who do attempt to achieve their pined for goals put more in protections trade. The financial specialists who are submitted and are constantly started toward their work put more in the securities exchange. There is a critical connection between sympathy and investment choices. When there is a one-point increment in sympathy it will get a negative difference in 0.088 focuses on the investment choices of financial specialists. At the point when the speculators comprehend the other's see the point then they put less in a financial exchange. There is a huge connection between social aptitudes and investment choices. When there is a one-point increment in social abilities it will bring a negative difference in 0.165 focuses on the investment choices of speculators. It shows that when an individual has social aptitudes, they put more in the financial exchange. As a financial specialist become increasingly charming and dependable, they attempt to comprehend the general public and put more in the securities exchange.

\subsection{Overall relationship among emotional intelligence, behavioral biases and investment decisions of the investors}

This part deals with the overall relationship among the behavioral biases, emotional intelligence and the investment decisions of the investors. After testing the relation between the different dimensions of the behavioral and investment decisions and the different dimensions of the emotional intelligence and the investment decisions of the investors, the overall relationship among the behavioral biases, emotional intelligence and the investment decisions of the investors has been studied. On the basis of this, the following hypotheses are framed:

HO. There is no relation between emotional intelligence and investment decisions of investors.

H1. There is relation between emotional intelligence and investment decisions of investors.

HO. There is no relation between behavioral biases and investment decisions of investors.

H2. There is relation between behavioral biases and investment decisions of investors.

Table 3 demonstrates that the fitted model is factually critical at $p<0.05$. The outcome from the numerous relapse investigation demonstrates that the model determines an expectation level at 0.661 or $66.1 \%$. The $R^{2}$ esteem decides 0.437 or $43.7 \%$ for each penny clarifies the inconstancy of the reliant variable. It demonstrates how precisely a model of relapse will foresee the future results. The most astounding estimation of emotional knowledge shows that enthusiastic insight predicts the venture choices superior to behavioral predispositions. At the point when there is a one-point increment in enthusiastic knowledge, it will bring a positive difference in 0.579 focuses on the venture choices of the speculators. When there is a 
RAMJ

14,1

44

one-point increase in behavioral biases it will bring a positive change of 0.212 points in the investment decisions of the investors (Table 3).

Therefore, there is a significant relationship between emotional intelligence, behavioral biases and the investment decisions of the investors. The investors who score high on emotional intelligence invest more in the stock market. Behavioral biases also predict the investment decisions of investors.

\section{Findings and suggestions}

The investigation found that the positive connection between the conduct predispositions of the financial specialists and venture choices of the speculators and positive connection between enthusiastic insight of the financial specialists and their venture choices. Yet, we found that the enthusiastic insight better foresees the venture choices of the financial specialists than the conduct predispositions of the speculators. Among the different elements of conduct inclinations of the speculator's lament and carelessness are identified with the financial specialist's venture choices. Among the various estimations of eager understanding - care, dealing with emotions, motivation, empathy and social aptitudes are related to the hypothesis decisions of the monetary pros. The examination shows that out of these two passionate insights and social predispositions of the speculators, enthusiastic knowledge impact venture choices of the financial specialists more than the conduct inclinations of the financial specialists. The financial specialists who consider their past experience put more and put safely in securities exchange and go out on a limb. Everyone will have the experience of feeling mourn for the duration of regular daily existence and it is common. The money related pros feel regret when they buy at a significant expense and offer to require little to no effort. They will in general hold the stocks excessively long until the moment that the expense accomplishes lower than the buying cost. The theorists who reliably do attempts toward the pined for targets or vanquishing negative sentiments put more in protections trade. The speculators who are submitted and are constantly started toward their work put more in the securities exchange. The theorists should have been full data of the endeavor streets. In this way, the associations should give complete consideration to the money related pros, which help them to pick the right theory at the perfect time. The hypothesis associations ought to deal with the theorists according to their social inclinations and the energetic understanding property while placing assets into protections trade. The individual money related master should not take after the theorists who consider their past experience or who contribute basically in light of the fact that other budgetary experts put assets into that particular street. Thus, the associations need to base on the individual examiner for getting the whole market. The reserve associations should design the endeavor streets according to the conduct inclinations and the enthusiastic information on the monetary authorities. The associations must offer some motivator added organizations to examiners. The financial specialists must not pursue most of the individuals. He ought to know about his ventures while putting resources into any stock. The financial specialists ought not to put resources into stock on the guidance of the others.

Table 3.

Coefficients from multiple regression model
Intercept $=0.408, \mathrm{R}=0.661, \mathrm{R}^{2}=0.437$ and $\mathrm{F}=192.831$

Dependent variable (investment decisions)

\begin{tabular}{lcrc} 
Independent variables & $\beta$ & $t$ & Sig. \\
\hline Behavioral biases & 0.212 & 5.404 & 0.000 \\
Emotional intelligence & 0.579 & 14.226 & 0.000 \\
\hline
\end{tabular}


The financial specialist ought not to put together their venture depending on respect to the exhibition of the stock previously. The money related counsels should concentrate on the arrogance and lament conduct predispositions of speculators while settling on venture choices with the goal that they can guide them precisely so as to reduce such sort of inclinations. Speculators ought to show restraint when taking venture choices. Financial specialists ought to painstakingly recognize and examine the social element, which influences the venture choices of the speculators. The financial specialist needs to build their insight with respect to social accounts. The speculators of all age bunches must have information with respect to the venture, so they can choose the best speculation road in like manner. The organizations ought to give data to the financial specialists with respect to the advantages of making interest in securities exchange.

\section{Conclusion}

The financial specialists decide their venture choices as per their behavioral predispositions and enthusiastic knowledge. The financial specialists with various enthusiastic knowledge put resources into various roads. The organizations ought to consider the distinctive behavioral inclinations and enthusiastic knowledge of the speculators keeping in mind the end goal to give them the best venture avenues. Thus, the companies should give the best advice to their clients on the basis of the different factors affecting the investment decisions of the investors.

\section{References}

Avsec, A., Taksic, V. and Mohoric, T. (2009), "The relationship of trait emotional intelligence with the big five in Croatian and Slovene university student samples", Psihološka Obzorja/Horizons of Psychology, Vol. 3 No. 18, pp. 99-110.

Bashir, T., Azam, M.S., Butt, M.S., Javed, M.S. and Tanvir, M.S. (2013), "Are behavioral biases influenced by demographic characteristics and personality traits? Evidence from Pakistan", European Scientific Journal, Vol. 9 No. 29, pp. 277-293.

Chavali, K. and Mohanraj, P. (2016), "Impact of demographic variables and risk tolerance on investment decisions: an empirical analysis", International Journal of Economics and Financial Issues, Vol. 6 No. 1, pp. 169-175.

Chin, A.L. (2012), "The relationship between psychological biases and the decision making of investor in Malaysian share market", International Conference on Management, Economics and Finance (ICMEF 2012) Proceeding, Malaysia, pp. 429-449.

Ezadinea, N., Fathi, S. and Salami, S. (2011), "The effect of emotional intelligence on portfolio performance of stakeholders: empirical evidence from Iran", Interdisciplinary Journal of Contemporary Research in Business, Vol. 3 No. 5, pp. 679-685.

Garkaz, M. and Mehrvarzi, M. (2012), "Examining the relationship between emotional intelligence and brokerage firms' performance in Tehran stock exchange", International Research Journal of Applied and Basic Sciences, Vol. 4 No. 3, pp. 886-890.

Goleman, D. (2001), "Emotional intelligence: Issues in paradigm building”, in Cherniss, C. and Goleman, D. (Eds), The Emotionally Intelligence Workplace, San Francisco: Jossey Bass.

Hameed, A. (2012), 'A Study on Factors Influencing Investment Decisions with Special Reference to Individual Investors in Tiruchirappall District', Doctor of Philosophy, Jamal Mohamed College, Tiruchirappalli.

Inaishi, R., Toya, K., Zhai, F. and Kita, E. (2010), "Effect of overconfident investor behavior to stock market", Journal of Advanced Computational Intelligence and Intelligent Informatics, Vol. 14 No. 6, pp. 661-668. 
RAMJ

14,1

Kunnanatt, J.T. (2004), "Emotional intelligence: the new science of interpersonal effectiveness", Human Resource Development Quarterly, Vol. 15 No. 4, pp. 489-495.

Landa, J.M., Martos, M.P. and Lopez-Zafra, E. (2010), "Emotional intelligence and personality traits as predictors of psychological well-being in Spanish undergraduates", Social Behavior and Personality: An International Journal, Vol. 38 No. 6, pp. 783-794.

Masomi, S.R. and Ghayekhloo, S. (2011), "Consequences of human behaviors' in economic: the effects of behavioral factors in investment decision making at Tehran stock exchange", International Conference on Business and Economics Research, Vol. 1, pp. 234-237.

Muttath, B. and Menachery, A. (2018), "Impact of emotional intelligence on investment decisions", Journal of Management Research and Analysis, Vol. 5 No. 1, pp. 255-260.

Nawi, N.H., Redzuan, M. and Hamsan, H. (2012), "Inter relationship between emotional intelligence and personality trait of educator leaders", International Journal of Academic Research in Business and Social Sciences, Vol. 8 No. 8, pp. 223-237.

Pervez, S. (2014), "Effect of emotional intelligence and financial literacy on investment decision making with a mediating role of risk perception", Jinnah Business Review, Vol. 12 No. 2, pp. 12-20.

Pirayesh, R. (2014), "A study on the effect of emotional intelligence on retail investors' behavior ", Management Science Letters, Vol. 4 No. 1, pp. 3-48.

Raheja, S. and Dhiman, B. (2019), "Relationship between behavioral biases and investment decisions: the mediating role of risk tolerance", DLSU Business and Economics Review, Vol. 29 No. 1, pp. 31-39.

Ramanujam, V. and Ramkumar, G. (2012), "Risk attitude and personality traits among working women managers in stock market operation with special reference to selected districts in Tamil Nadu", Paripex - Indian Journal of Research, Vol. 2 No. 12, pp. 131-135.

Sami, A. and Rizvi, T. (2013), "Emotional intelligence and personality traits as predictors of life satisfaction among aged persons", Projournal of Humanities and Social Science, Vol. 1 No. 1, pp. 1-9.

Sashikala, V. and Chitramani, P. (2017), "A review on emotional intelligence and investment behavior", International Journal of Management, Vol. 8 No. 3, pp. 32-41.

Tanvir, M., Sufyan, M. and Ahsan, A. (2016), "Investors emotional intelligence and impact on investment decision", International Journal of Academic Research in Economics and Management Sciences, Vol. 5 No. 3, pp. 12-28.

Zahera, S. and Bansal, R. (2018), "Do investors exhibit behavioral biases in investment decision making?”, Qualitative Research in Financial Markets, Vol. 10 No. 2, pp. 210-251.

Zaidi, F.B. and Tauni, M.Z. (2012), "Influence of investor's personality traits and demographics on overconfidence bias", Interdisciplinary Journal of Contemporary Research in Business, Vol. 4 No. 6, pp. 730-746.

\section{Further reading}

Chou, S., Huang, G. and Hsu, H. (2010), "Investors attitudes and behavior towards inherent risk and potential returns in financial products", International Research Journal of Finance and Economics, pp. 16-30.

Gaur, A., Julee, A. and Sukijha, S. (2011), "Difference in gender attitude in investment decision making in India”, Research Journal of Finance and Accounting, Vol. 2 No. 12, pp. 1-6.

Jains, D. and Dashora, N. (2012), "A study on impact of market movements on investment decision "an empirical analysis with respect to investors in Udaipur, Rajasthan”, Journal of Arts, Science and Commerce, Vol. 2 No. 2, pp. 78-88.

Okpara, A. and Edwin, A. (2014), "Workplace emotional intelligence and return on investment in the Nigerian banking industry", Journal of Management, Marketing and Logistics, Vol. 1 No. 4, pp. 348-374.

Wang, A. (2009), "Interplay of investors financial knowledge and risk taking", The Journal of Behavioral Finance, Vol. 10 No. 4, pp. 204-213. 


\begin{abstract}
About the authors
Dr Saloni Raheja is an Assistant Professor in the Department of Commerce and Business Management (CBM), DAV University, Jalandhar. She has completed her $\mathrm{PhD}$ from Lovely Professional University, Phagwara. Her research is focused on the area of behavioral finance, investment decisions, accounting and management and the stock market. She has presented papers in various national and international conferences and has published different research papers in the journals of national and international repute (including SCOPUS indexed, Thomson Reuters' and SAGE journals). She has an experience of more than six years in academics and research. She has also done an Advance Diploma in Insurance and Risk Management. She has attended various FDP programs and organized different workshops. Saloni Raheja is the corresponding author and can be contacted at: saloni.rahejaa@gmail.com

Dr Babli Dhiman is presently working as Professor and Head Finance Department in the Mittal School of Business. She is a member of editorial and review boards of various reputed journals. She has an exposure of $20+$ years of working in academics, holding international finance conferences, the funded research project of ICSSR, editor for SCOPUS index journal. She is handling administration and curriculum development for finance related areas. She has also supervised $20+$ students for MPhil and $\mathrm{PhD}$. She has $75+$ research papers published and presented in various reputed journals, seminars and conferences.
\end{abstract}

For instructions on how to order reprints of this article, please visit our website: www.emeraldgrouppublishing.com/licensing/reprints.htm Or contact us for further details: permissions@emeraldinsight.com

\section{Emotional intelligence}

